\title{
Vetiver Finish in Surgical Medical Products
}

\author{
D. Anita Rachel ${ }^{1}$, A. Subashini ${ }^{2}$ \\ ${ }^{1}$ Assistant Professor, ${ }^{2}$ III Yr B.Sc(AMM) \\ Nift - Tea College of Knitwear Fashion, Tirupur, Tamil Nadu, India
}

\section{ABSTRACT}

Textiles are an integral part of everyone's life associated with him from cradle to grave. It is used to cover human body, thus encompassing and protecting it from dust, sunlight, wind and other foreign matter present in the external environment that may be harmful to him. Textiles in apparel have retained an important place in human life, starting now into developing of newer high technology and interdisciplinary products. Among technical textiles, medical textiles are a very promising sector which plays a vital role in health of mankind. It consists of textiles used in operative and post-operative tasks in and around the patient and the medical practitioners. These products are produced either by weaving, knitting, braiding or other nonwoven techniques. Medical textiles are broadly classified as nonimplantable materials, implantable materials, extra corporeal devices, and hygiene products, protective and health care textiles. The use of such products helps to reduce the opportunity for contamination by biological toxins and infectious pathogens. A hygiene and health care textile consists of absorbent disposable products, such as baby infant tank wears, tampons, panty shields, etc. which are mostly single use items. Baby infant tank wears are made up of cotton fibres A Progress of vetiver finish in the Surgical Products such as Mask, Cap and Gown to kill the growth of microbes. Bacterial growth is one of the biggest fallout of non-hygienic atmosphere. Further microorganisms such as bacteria, mould and fungi also cause deterioration of textiles. Hence there has been greater interest in textiles and garments that offer enhanced comfort as well as protection to the wearer. Hence to prevent such rashes some kind of an antibacterial finishes is essential. The vetiver finishes in the surgical products are subjected towards Survey.

Key Words: Health care textiles, Surgical Products, antimicrobial finish, Vetiver root essence and survey

\section{INTRODUCTION}

\subsection{NONWOVENS:}

The use of nonwoven for medical purposes goes all the way back to WWII (World War II), which precipitated a big demand for easily deployed medical products. As the technology gradually improved, nonwovens proved to be a superior to woven products in terms of disposability, adaptability, effectiveness and cost. It is possible to dispose of potentially contaminated items, nonwovens provided effective barriers against bacteria. They were also better than linens for air-borne contamination reduction

\section{OBJECTIVES:}

1. To produce health hygiene disposable mask

2. To produce disposable surgical gown

3. To produce surgical medical head cap

4. To survey the usage of natural finished surgical medical products in hospitals

5. To incense the medical sense towards natural finished garments

6. To collect the testimony report on the disposable mask, surgical medical glouse, disposable surgical gown

\subsection{NONWOVEN IN MEDICAL APPLICATIONS:}

Nonwoven have a well established reputation for conforming to the special needs/demands of medical textiles as it contains

$>$ Uncanny effectiveness and efficiency

$>$ High performance (vapour transmission, air permeability, comfort, feel etc.)

$>$ Superior barrier providing capacity

$>$ Excellent user protection (high tearing \& abrasion resistance)

$>$ Unbeatable wound caring (absorbent pads, drugdelivery devices, bandages

Well documented usage in ICU, labs, operating rooms etc. 


\subsection{KEY CHARACTERISTIC OF NONWOVEN FABRIC:}

$>$ Dimensional stability

$>$ Strength

$>$ Durability

$>$ Resilience

$>$ Low elongation

$>$ Porosity level controlled based on specific processing

The value of non-woven fabrics in an implantable medical device include:

$>$ High degree of tissue in-growth

$>$ Controlled permeability

$>$ Low degree of elongation

$>$ Absorbency

\section{GARMENT FINISHING:}

In garment finishing is applied once the garment is fully made, it is used to improve its appearance, feel and other properties.

\subsection{ANTIBACTERIAL FINISH:}

A treatment to reduce the growth of bacteria and to kill the bacteria by the application of finishing agent(vetiver)

\subsection{VETIVER:}

(VETIVERIA ZIZANIOIDES) Vetiverira derived from theTamil word VETIVER meaning "root that is dung out" and zizanioides means "by river side". As the name indicates, it is most commonly found along the water beds. Vetiver is a tall, tufted, perennial, scented grass, with a straight stem, long narrow leaves and erect culms up to 2 meters height and over 2.5 meters with flower head. Vetiver oil is used in traditional medicine and perfumery since ancient times.

\section{METHODOLOGY:}

Identification of antibacterial finishing agent

Extraction of roots

Pad dry cure finish

\subsection{PAD DRY CURE TECHNIQUE:}

Pad dry cure or exhaust dry cry is a finishing process applied to textiles to impart different finish treatments, such as waterproofing, softening, antibacterial or anti odor finishes. The garment is passed through a water based solution bath containing the finishing chemicals.

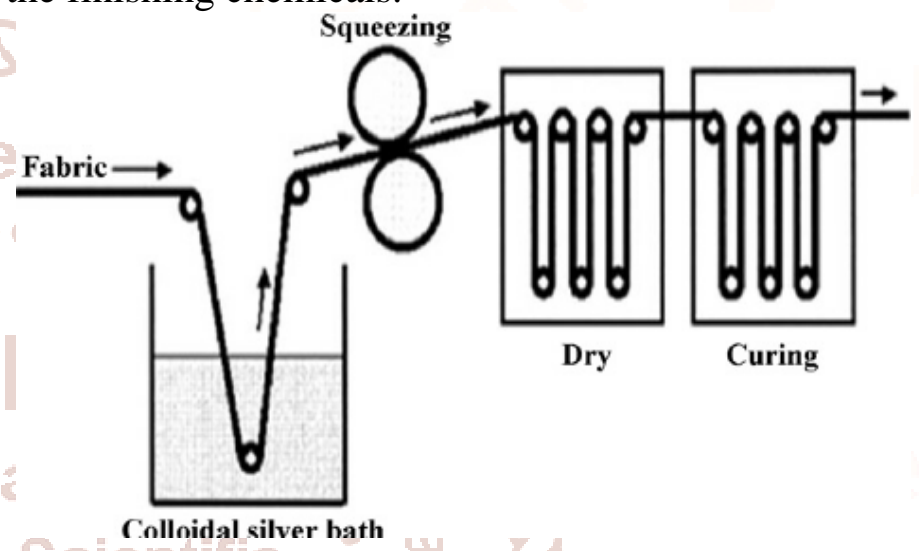

1). HEALTH HYGIENE DISPOSABLE MASK:

Health hygiene disposable nonwoven mask prevents skin irritation, Bacteria filtration efficiency for single ply $80 \%$, for double ply: $85 \%$ \& for three ply : $97 \%$ pleated for full face coverage, adjustable pvc coated aluminium nose clip and soft thread elastic ear bands or lace, filters dust particles size up to 4 microns, sonic sealing \& proper placement of folds. Cool \& breathable, lint Free.

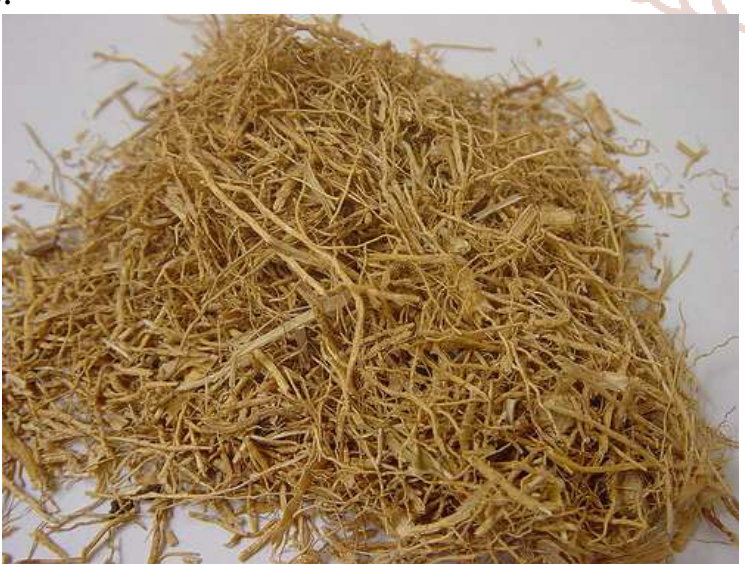

BOTANICAL NAME: VETIVERA ZIZANIOIDES

FAMILY: POACEAE

USAGE: ROOT

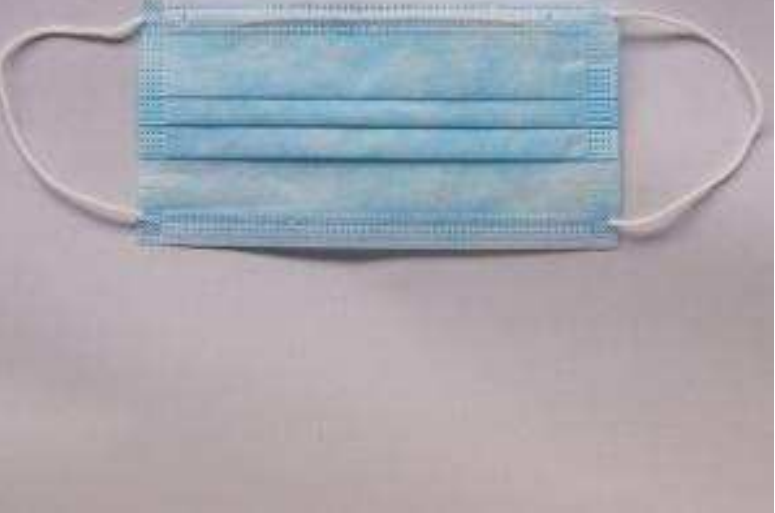


The above disposable face mask is made from nonwoven fabric, mesh fabric as the main raw material. This material is preferred for its light weight. It has excellent water repellence and air permeability resulting in providing comfort \& dryness resulting in antibacterial and antifungal resistance by nature.

\subsection{SOURCE AND DESCRIPTION:}

$>$ Sourcing of vetiver root and making it into the powder form.

$>$ Addition of hot water in water bath

$>$ Mixing of vetiver root powder in required quantity

$>$ Dissolving the disposable surgical mask in addition to the water for $8 \mathrm{hrs}$

$>$ Pad dry cure technique

\section{PAD DRY CURE TECHNIQUE:}

Here padcure is for antibacterial finishing to the garment in application for health hygiene disposable mask.

\section{DISEASE CONTAMINATION:}

Surgical face mask are intended to be used in order to help or prevent large particles expelled by the wearer (e.g. spit, mucous) from reaching the patient or work environment. Vetiver finished surgical masks are good resistance towards bacteria and acts a barrier to kill bacteria. It helps to prevent the bacteria that we inhale through our mouth and nose.

\section{2). SURGICAL MEDICAL GOWN:}

Surgical gowns are used by doctors and nurses as protective clothing in the operation theatre to prevent the spread of bacteria from patients to surgical staff and therefore, reduce the incidence of hospital acquired infections. All humanblood and other body fluids are treated as infectious to human health; act as acarrier and transport the bacteria through the fabric, which can cause serious ill-ness or death. During surgical procedures, surgeons may be exposed to sprays ofblood or other body fluids containing pathogens. Several researchers have reported a direct correlation between wetting by liquids and bacterial penetration of surgical drape and gowns. Healthcare workers' uniforms including surgical gowns are used as barriers to eliminate the risk of infection for both doctor and patient. The prevalence of human immunodeficiency virus, hepatitis $\mathrm{B}$ and $\mathrm{C}$ viruses in the patient population is very common.

\subsection{SOURCE AND DISCRIPTION:}

$>$ Sourcing of vetiver root and making it into the powder form.

Addition of hot water in water bath

$>$ Mixing of vetiver root powder in required quantity Dissolving the disposable surgical gown in addition to the water for $8 \mathrm{hrs}$

Pad dry cure technique

\section{PAD DRY CURE TECHNIQUE:}

Here pad cure is for antibacterial finishing to the garment in application for disposable surgical gown.

\section{DISEASE CONTAMINATION:}

Surgical gowns are intended to be used in order to help or preventbacteria from entering into our body. Vetiver finished surgical gown are good resistance towards bacteria and acts a barrier to kill bacteria. It acts as a protector to our body.

\section{3). SURGICAL MEDICAL HEADCAP:}

We are engaged in providing Nonwoven Surgical Caps in White, blue and green colour. These Nonwoven Surgical Caps are made as per the requirements of Health \&Medical Care industry. Nonwoven Surgical caps helps cover the entire head and scalp area. As the hair and scalp area contain large area of micro-organisms and these bacteria when released during surgical procedure can be problematic. This head cap is the most effective way to ensure hygiene.

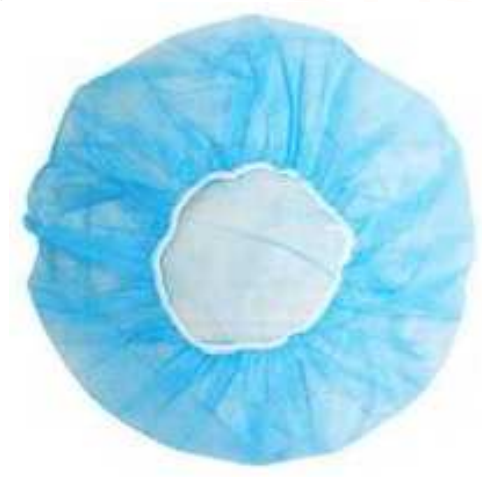




\subsection{SOURCE AND DISCRIPTION:}

$>$ Sourcing of vetiver root and making it into the powder form.

$>$ Addition of hot water in water bath

$>$ Mixing of vetiver root powder in required quantity

$>$ Dissolving the disposable surgical head cap in addition to the water for $8 \mathrm{hrs}$

$>$ Pad dry cure technique

\section{PAD DRY CURE TECHNIQUE:}

Here padcure is for antibacterial finishing to the garment in application for disposable surgical medical head cap.

\section{RESULT:}

Thus the three nonwoven surgical products are given antibacterial finish using vetiver and testing reports analysed for colour fastness towards washing and colour fastness towards light and getting a testimony report from a medical surgeons. The Colour fastness rates 4 to 5 so it comes under good grade of colour fastness rating. The products are analysed and reports are tested for its colours fastness towards washing and light. Testimony report is certified from the medical surgeon with the objective questionnaires analysis type and the survey is exciquited.

\section{CONCLUSION:}

In this study, antibacterial property of vetiver is identified and finishing is applied to the nonwoven surgical products, as the surgical products contains more amount of bacteria from the hospitals and surrounding atmosphere due to contact of patients. By giving vetiver finish to the nonwoven surgical products it acts a killing agent towards bacteria and gives protection to the wearer.

\section{REFERANCE:}

1. O. L. Shanmugasundram, antibacterial finish in textiles. THE INDIA text.t.,2007,52(3):10-17

2. S. Mishra, K, Sharma, S. Mohapatra and Chauhan. $\mathrm{D}$, An overview on Vetiverira zizanioides

3. Kumar, s., and Gayathri, k., 2016, Chemical characterization of vetiveria zizanioides linn root. Int. J. Fiber text. Res.,37 (02)

4. S. Fijan and S. S Turk, Hospital textiles, are they a possible vehicle for healthcare associated infections Int. J. Environ. Res.Public health,2012,9

5. H Mucha, D Hoter and M Swerev: Antimicrobial Finishes and Modifications, Melliand International, May 2002, Vol 8, pp 148-151.

6. I Home: Antimicrobials Impart Durable Finishes, International Dyer, December 2002, pp 9-11.

7. Rajendran and S C Anand: Development of Versatile Antimicrobial Finish for Textile Materials for Health Care and Hygiene Applications, Bolton Institute, UK.

8. D Gupta: Antimicrobial Finishing of Textiles, www.resil.com.

9. E Menezes: Antimicrobial Finishing of Textiles, The Textile Industry and Trade Journal, JanuaryFebruary 2002, pp 35-38. 